\title{
The Relationship between Evidentiality Development and Theory of Mind in School-Aged Children
}

\author{
Ji Hyun Lee, Hee Ran Lee \\ Department of Speech and Hearing Therapy, Catholic University of Pusan, Busan, Korea
}

Correspondence: Hee Ran Lee, PhD Department of Speech and Hearing Therapy, Catholic University of Pusan, 57 Oryundae-ro, Geumjeong-gu, Busan 46252, Korea Tel: $+82-51-510-0841$

Fax: +82-51-510-0848

E-mail: hrlee@cup.ac.kr

Received: March 28, 2016

Revised: May 10, 2016

Accepted: May 16, 2016

This work is based on the master's thesis of the first author.

\begin{abstract}
Objectives: The present study examined Korean school-aged children's comprehension of evidential markers (-ne(-eo), -dae(-rae), -geot gatda) and whether the development of theory of mind (ToM) contributes to evidential marker understanding. For the development of evidentiality, it is necessary to comprehend how one acquired the information he or she understood, including the information transmitted from others. Methods: Seventy-two typically developing Korean children (2nd, 4th, and 6th grade) participated in this study. The children's comprehension of three evidentiality marking tasks (direct experience, indirect experience, and indirect inference) was tested using pictures and test sheets. The four types of ToM were measured using listening comprehension tasks. Results: There were significant differences between the 2nd and 4nd, and 2nd and 6th grades in the comprehension of indirect experience and indirect inference markers. But there were not significant grade differences in the comprehension of direct experience markers. The development of ToM according to grade was statistically significant in all groups. Development of ToM showed positive correlations with indirect experience markers, indirect inference markers, and the total scores of evidential markers except for direct experience markers. Conclusion: These results indicate that the development of ToM and grammatical markers is useful for assessment and intervention concerning the language ability of school-age children.
\end{abstract}

Keywords: School-aged children, Evidentiality development, Theory of mind, Pragmatic development
학령기는 부모나 가족이라는 일차적인 관계에서 학교와 친구로 또 다른 인간 관계가 발달하는 시기이며, 아동의 직접경험과 관련 된 정보가 의사소통의 대부분을 차지하던 학령전기에 비해 보다 다양해진 상호작용 상황들을 통해 주어지는 정보를 선택적으로 받아들이게 되는 시기이기도 하다. 즉, 아동 스스로 직접 경험한 것 에 덧붙여 또래와 선생님 또는 교육 매체 등에서 제공받는 수많은 정보들을 접하게 된다. 특히 개인적으로 경험한 것 이외에 문해력 지식을 기반으로 한 탈문맥적인 이야기나 대화 상황에서 습득하는 담화 측면의 기술들이 점차 중요해지면서(Gleason, 2005; Lee, 2007; Paul, 2012; Scott, 1994) 정보의 원천에 대한 판단과 해석을 포함한 화용능력 역시 세련되게 발달해 간다.
다양한 담화상황에서 주어지는 정보를 판단하는 능력은 학령기 아동이 습득해야 할 중요한 발달 과제이다. 대화 상황에서 화자의 의사소통 의도를 정확하게 파악하기 위해서는 대화 상대방과 더불 어 신념과 추론을 공유할 수 있어야 하는데, Grice $(1975,1978)$ 는 화자와 청자 간의 대화 상황에서 이뤄지는 협응(cooperation)을 인 간 의사소통의 근본적 특성으로 부여하였다. 성공적인 의사소통 에 영향을 미치는 공통기반(common ground)을 형성하여 대화 상 대방이 제공하는 다양한 정보를 받아들이고 해석하기 위한 협응 적 노력은 결국 다른 사람의 마음을 정확하게 읽어내는 능력과도 밀접하게 관련되어 있음이 알려져 있다. 따라서 화자로서 적절한 정보를 제공하는 역할뿐만 아니라, 전달받은 내용의 타당성을 평가 
하여 바르게 해석하고, 화자의 의도를 추론하여 이해하는 청자로 서의 역할은 학령기 아동의 담화 능력 발달에 중요한 변인이 될 것 이다.

학령기 아동이 스스로 또는 청자로부터 습득하는 지식과 관련 한 정의를 살펴보면, 정보의 성격에 따라 지식의 종류를 직접 지식 (direct knowledge)과 간접 지식(indirect knowledge)으로 나눌 수 있다(Song, 2009). 직접 지식은 화자가 직접 목격하였거나 경험하여 획득한 정보이고, 간접 지식은 보고된 내용과 추론을 통해 획득한 정보이다. Aikhenvald (2004)는 화자가 전달하는 정보의 유형을 화 자의 직접 경험과 간접 경험에 의해 구분할 때, 이렇게 습득된 다양 한 정보의 출처를 밝히고 정보의 습득 방법을 표시하는 것을 '증거 성(evidential)'이라 하고, 이러한 표현 체계를 문법적으로 나타내는 것을 '증거성 표지(evidentiality)'라고 하였다.

한국어에서는 다른 사람을 통해 전해들은 간접적인 경험 정보에 대해 '-대'를 표현하거나, '-것 같아(-나봐)'처럼 간접적 단서에 대해 추론할 때 사용하는 양태(modality)로써의 문법 표지들이 보고되 고 있다(Song, 2009). 본 연구에서는 언어학계에서 증거성 표지로 일컬어지고 있는 경험과 추론을 나타내는 문법 표지에 대한 학령 기 아동의 발달 특성을 살펴보고자 하였다.

경험과 추론을 나타내는 문법 표지를 이해하고 사용할 수 있는 능력은 적절한 정보를 선택하고, 선택된 정보를 정확하게 전달하는 과정에서 매우 중요하다. 특히, 다양한 정보들을 이용하여 담화상 황에서 자신의 태도를 결정해야 할 때, 어느 정보가 더 확실한지 판 단하고 그에 따라 합리적인 결정에 도달할 수 있으려면, 적절한 문 법 표지를 잘 선택하여 사용하여야 하기 때문이다. Kim (2012)에 따르면, 동일한 정보일지라도 화자의 관점과 시각을 바탕으로 이뤄 진 직접적인 정보는 추론이나 보고에 의한 간접적인 정보보다 높은 신뢰성을 드러낸다고 한다. 따라서, 학교라는 새로운 환경에서 많은 정보를 접하게 되며, 자신이 접하는 수많은 정보 가운데 선택하고 참고해야 할 정보들을 판단하는 능력을 키워가야 하는 학령기 아 동에게 이러한 특정 문법 표지의 숙달은 화용능력을 포함한 전반적 인 의사소통 능력을 향상시키는 데 매우 필수적이라고 할 수 있다.

한국어의 문법 표지 즉, 문법형태소는 대부분 학령 전기에 발달 이 완성되는 것으로 알려져 있다(Jung \& Pae, 2010; Lee, 2000; Lee \& Hwang, 2002; Pae, 2006; Seo \& Lee, 1999). 그러므로 학령기의 문법 표지에 관한 연구들의 대부분은 아동들이 상위언어적 지식 을 토대로 문법적으로 정확한 문장과 비문법적인 문장의 차이를 판단할 수 있는지와 관련된 연구 결과들을 보고하고 있다(Jeong \& Hwang, 2007; Kim, 2003). 하지만, 본 연구에서 살펴보고자 하는 경험과 추론을 나타내는 문법 표지의 발달은 학령기에 이르러서도
성인 수준에 이르기 어려운 문법 표지들이라고 할 수 있다. 경험과 추론을 나타내는 문법 표지의 발달은 크게 산출과 이해의 두 가지 영역으로 나누어 살펴볼 수 있을 것이다. 직접경험을 나타내는 표 지인 '-어'와 '-네'는 1 세 중반에 자발적 산출이 나타나기 시작하여, 3세 정도가 되면 대부분의 아동들이 비교적 정확하게 산출하게 되 며, 간접경험 가운데 타인에 의한 보고를 나타내는 '-대'와 같은 어 미는 2 세경에 자발적 산출이 나타나지만 3 세가 되어야 성숙한 산 출이 나타나기 시작한다(Lee, 2009; Papafragou, Li, Choi, \& Han, 2007). 이에 반해, 간접추론을 나타내는 문법 표지인 '-것 같다'는 4-5세가 되어야 자발적 산출이 관찰되어 상대적으로 발달이 느린 것으로 나타났다(Lee, 2009). 이러한 산출과 비교할 때, 문법 표지 의 이해 발달은 직접경험 표지 '-어(네)'가 2세경에 발달하지만, 간 접경험 표지 '-대'와 간접추론 표지 '-것 같다'는 6세에도 아직 성인 수준에는 이르지 못해 비교적 서서히 발달하는 것으로 나타났다 (Choi \& Kaufman, 2009; Choi, Lee, \& Jang, 2010). 이는 타인의 경 험을 전달하는 데 사용되는 문법 표지 자체의 이해와 표현에서의 어려움이라기보다는, 표지로 전달하고자 하는 정보의 원천이 되는 타인에 대한 이해와 추론에 관련된 인지 능력과 협응 능력의 발달 이 이러한 문법 표지에 기여하기 때문일 것이다.

요약하자면, 경험과 추론을 나타내는 문법 표지의 산출과 이해 는 자신과 대화 상대방이 대화를 위해 얼마나 성공적으로 공통기 반에 따라 협응하고 있는지를 기반으로 이뤄진다고 하겠다. 따라서 자신이 알고 있는 정보의 원천에 대한 이해와 더불어, 타인이 전달 하고자 하는 정보를 어떠한 방식으로 습득하였는지에 대한 이해 역시 중요하므로, 믿음이나 바람, 의도와 같은 내적인 마음 상태에 서 자신이나 타인의 행동이 나타남을 이해하는 능력인 마음읽기나 마음이론(theory of mind)과도 연관될 가능성이 클 것이다.

마음이론은 타인의 생각을 추론할 수 있는 능력으로, 자신의 생 각을 효율적으로 전달하거나 타인의 행동을 예측하고 설명하게 함 으로써 의사소통을 가능하게 한다. 마음읽기가 성공적인 의사소 통에 필수적으로 기여하는 역할은 청자가 필요로 하는 정보를 말 하는 이가 고려하도록 해준다는 점이다. 화자는 청자가 무엇을 알 고 있는지 또는 알지 못하는지, 그리고 청자가 소통 의도를 이해하 도록 하기 위해서는 자신이 어떠한 정보를 제공해야 하는지를 파 악해 전달해야만 한다. 가정 생활과 일상적인 환경에서의 의사소 통이 주를 이루던 학령전기와는 다르게, 학령기 아동은 학교라는 새로운 상황에서 사회적인 의사소통을 하게 된다. 학교 환경에서의 의사소통은 말로 이뤄지는 상호작용에 덧붙여 말로 표현하지 않는 다양한 규칙을 포함한 ‘숨겨진 교과과정’(hidden curriculum)도 다 뤄진다(Westby, 2006). 이와 더불어, Ghim 등(2007)의 연구에 따르 
면 학령기에도 지속적으로 발달하는 마음이론 능력에는 애매한 행동의 다양한 의미를 파악하는 능력, 상대방의 말을 문자 그대로 이해하지 않고 숨은 뜻을 알아내는 능력, 그리고 상대방의 말실수 를 알아채고 그 말이 실수였다는 것을 이해하는 능력 등이 포함된 다고 하였다. 따라서 이러한 마음이론 능력은 학교 상황에서 이루 어지는 사회적인 담화를 이해하는 과정과 근본적으로 관련되어 있 으며, 아동의 전반적인 언어이해력과도 관련이 높다고 할 수 있다.

걸음마 시기의 유아들도 자신의 마음상태에 근거하여 행동에 대 해 말을 하기 시작하지만, 일반적으로 마음이론의 발달은 3-4세경 이 되어야 가능하다(Bartsch \& Wellman, 1995; Ghim \& Kim, 2002; Kim, 2001; Perner, Leekam, \& Wimmer, 1987; Wellman, 1990). 마 음이론 능력이 이처럼 학령전기에 이미 발달된다고 해도, 상대방이 하는 말의 숨은 뜻을 알아내는 능력이나 정서 추론 능력은 청소년 기에도 계속 발달한다고 한다(Ghim et al., 2007).

특히, 마음이론 가운데 틀린 믿음(false-belief)에 대한 이해는 언 어발달에서 구문론(Astington \& Jenkins, 1999; Choi, Jang, \& Lee, 2011; De Villiers, 2000) 또는 의미론적 발달이나 전반적인 언어능 력과 관련되어 있음이 알려져 있다(Ruffman, Slade, Rowlandson, Rumesy, \& Garnham, 2003; Song, 2006). 또한 Astington과 Baird (2005) 그리고 Lee, Lee와 Shin (2004)의 연구에서도 언어와마음이 론의 발달이 서로 관련성이 깊다고 보고되고 있다. 이 가운데 Choi 등(2011)은 3-6세 아동의 마음이론 수행 수준과 문법 표지 '-대'와 '것 같다'의 이해 및 산출이 유의한 상관을 보여 마음이론이 이러 한 형태론 습득에 영향을 미칠 수 있음을 제안하였다. 이들 연구에 따르면, 위의 두 가지 문법 표지는 4세 이후부터 발달하지만 6세까 지도 산출에 비해 이해에 어려움이 있으며 '-것 같다'보다는 '-대'의 산출이 보다 지연됨을 보고하고 있다. 하지만, 연구 절차상, 산출과 제의 경우 대상 아동이 실험자로부터 전달받은 비밀을 또 다른 실 험자에게 전달하게 하거나, 이해과제에서는 동영상을 통해 등장 인 물들의 상황을 이해하고 추론하여 '-야', '-대(래)', '것 같아'가 포함 된 문장을 누가 사용하는지를 선택해야 했으므로, 학령전 아동을 대상으로 하기에는 과제의 난이도가 매우 높았던 점이 연구의 제한 점으로 남는다.

따라서 본 연구에서는 학령기 아동들을 대상으로 이러한 문법 표 지의 이해 발달과 마음이론 간의 관련성을 알아보고자 하였다. 특 히, 선행연구들에서 학령전기에 안정적인 발달이 이루어지지 않았 던 '대(래)'와 '-것 같다'와같은 간접경험과 추론을 나타내는 문법 표 지의 이해 발달 정도를 초등학교 $2,4,6$ 학년 아동을 대상으로 살펴 보고자하였다. 또한이에 덧붙여 이러한 문법표지 발달이 마음이론 발달과 어떠한 관련성이 있는지를 체계적으로 고찰하고자 하였다.

\section{연구 방법}

\section{연구 대상}

본 연구에서는 부산지역 초등학교 2, 4, 6학년 일반아동 72 명을 대상으로 하였다. 연구대상 아동의 선정기준은 (1) 교사나 보호자 에 의해 발달이 정상적으로 이루어지고, 사회성과 신경계통이나 운동기능, 청각이나 시각과 같은 감각영역 등에 문제가 없다고 보 고된 아동, (2) 교육부에서 전국 초등학생을 대상으로 실시하는 기 초학력평가(2학년)와 교과학습 진단평가(4, 6 학년) 결과, 담임교사 로부터 60점 이상임이 확인되어 학습에 문제가 없는 아동, (3) 수 용·표현어휘력검사(Receptive and Expressive Vocabulary Test, REVT; Kim, Hong, Kim, Jang, \& Lee, 2009) 결과, 수용 및 표현어 휘력에서 모두 -1 SD 이상으로 언어능력이 정상범위에 있는 아동 을 대상으로 선정하였다. 연구대상자의 정보는 Table 1 과 같다.

\section{검사 도구}

\section{문법 표지 이해 과제}

본 연구에서는 학령기 아동을 대상으로 경험과 추론을 나타내 는 문법 표지 이해를 살펴보기 위해 Lee (2012)의 연구에서 사용한 문장 과제를 학령기 수준의 읽기 이해 과제로 수정하여 사용하였 다. 이를 위해 직접경험과 간접경험, 간접추론을 나타내는 각각의 상황을 문항별로 6 가지씩 총 18 개 객관식 문항을 제작하였다. 직접 경험 문항은 '-네(어)', 간접경험 문항은 '-대(래)', 간접추론 문항은 '-것 같다'(간접추론)로 다시 표현될 수 있으므로, 아동의 과제는 제 시된 각 문항(예: ‘준수는 혜민이가 영화관에 가는 것을 보았다')을 읽은 후, 적절한 문법 표지를 사용하여 다시 표현된(예: ‘혜민이가 영 화관에 갔어') 목표 문장을 4 가지 보기 가운데에서 찾는 것이었다.

18 개의 객관식 문항을 제작하는 과정에서 문법 표지에 대한 이 해 여부와 별개로 아동들이 자신의 말하기 스타일에 따라 검사 문 항의 답지를 선택할 가능성을 고려해, 유사한 문항을 다른 형식으 로(예: ‘2. 은희는 선물상자에서 달콤한 냄새가 나는 것으로 보아 선 물이 초콜릿이라고 추측하였다' vs. '9. 은희는 선물이 초콜릿이라 는 것을 준표에게서 전해 들었다') 질문함으로써, 아동의 말하기 스

Table 1. Participants' characteristics

\begin{tabular}{lrccr}
\hline Grade & Age (mo) & $\begin{array}{c}\text { Sex } \\
\text { (male:female) }\end{array}$ & $\begin{array}{c}\text { Receptive } \\
\text { vocabulary }\end{array}$ & $\begin{array}{r}\text { Expressive } \\
\text { vocabulary }\end{array}$ \\
\hline $2(\mathrm{~N}=25)$ & $99(3.41)$ & $13: 12$ & $98.68(14.26)$ & $98.00(12.09)$ \\
$4(\mathrm{~N}=25)$ & $122(3.53)$ & $12: 13$ & $127.17(19.49)$ & $124.08(20.32)$ \\
$6(\mathrm{~N}=22)$ & $146(4.75)$ & $11: 11$ & $147.18(15.36)$ & $145.32(15.33)$ \\
\hline
\end{tabular}

Values are presented as mean (SD).

${ }^{a}$ Receptive and Expressive Vocabulary Test (Kim, Hong, Kim, Jang, \& Lee, 2009). 
타일에 따른 반응 가능성을 가능한 배제하고자 하였다.

본 실험에 앞서, 문법 표지 이해를 평가하기 위한 문장과제에 대 해 초등학교에 재학 중인 2학년 5명, 4학년 2명, 6학년 4명 총 11명을 대상으로 예비실험을 실시하였다. 전반적인 검사내용에 대해 설명 을 해주었지만, 검사자가 들려주는 문장을 듣기만 하고 이해하는 과제에 대해 모든 학년에서 아동의 수행이 저조하였으므로, 본 실 험에서는 아동들의 이해를 돕기 위해 그림과제를 삽입하여 최종적 으로 문장과제를 제작하였다(Appendix 1).

\section{마음이론 과제}

학년(2, 4, 6학년)에 따른 마음이론 발달을 살펴보기 위해 본 연 구에서는 3 가지 유형(2차 순위 틀린 믿음, 모호한 상황, 말의 숨은 의미 파악)의 과제를 선정하였다. 2 차 순위 틀린 믿음 과제, 모호한 상황 과제(Bosacki \& Astington, 1999; O'Connor \& Hirsch, 1999), 말의 숨은 의미 파악 과제(Happé, 1994), 헛디딤 과제(Baron-Cohen, O'Riordan, Stone, Jones, \& Plaisted, 1999)를 토대로 만들어진 Choi (2007)의 17 가지 에피소드 중, 본 연구에서는 신뢰도와 타당 성이 확보된 과제를 중심으로 4 개의 과제만을 사용하였다. 특히, Choi (2007)의 연구에서 사용된 마음이론 과제 가운데 헛디딤 과 제는 중학생 정도가 되어야 어느 정도 이해가 가능한 것으로 해석 되었기 때문에, 초등학교 아동을 대상으로 하는 본 연구에서는 헛 디딤 과제를 제외하였다. 그 결과, (1) 특정 사실을 접하지 못해 틀린 믿음을 가진 사람의 마음과, 사실을 알고 있는 주인공의 마음을 아 동이 이해하는지 알아보는 ' 2 차 순위 틀린 믿음' 과제 1가지, (2) 모 호한 상황에 처한 주인공들의 마음과 기분에 대해 아동이 이해하 는지를 알아보는 '모호한 상황' 과제 1가지, (3) 명시된 말 그대로가 아니라 그 이면에 숨겨진 뜻을 파악하는지를 묻는 말의 '숨은 의미 파악' 과제(선의의 거짓말, 풍자) 2 가지로 전체 4 가지 과제를 구성하 였다(Appendix 2).

\section{내용타당도}

언어재활사 1 급 자격증을 소지한 언어발달 관련분야 전문가 5 명 에게 전체 18 문항에 대해 Likert 5 점 척도를 사용하여 문법 표지 이 해 과제의 내용타당도를 평가하게 하였다. 내용타당도 측정 결과 평균이 4.82 로 나타나 이해과제의 내용타당도가 높은 것으로 판단 하였다. 하지만, 전체 질문지 문장 가운데 수정이 필요한 부분을 제 언을 참고하여 수정·보완하였다.

\section{연구 절차}

검사는 대상 아동이 다니는 학교의 빈 교실의 책상에서 아동과
검사자가 마주보고 앉아 개별적으로 진행하였으며, 먼저 대상자 선 정을 위해 기초검사인 수용·표현어휘력검사(REVT; Kim et al., 2009)를 실시하였다. 기초 검사가 끝난 후, 5 분 정도의 휴식을 취하 고 본 검사를 실시하였다. 본 검사는 문법 표지 이해 과제부터 실시 하였고, 마음이론 과제를 포함하여 전체 20 분을 넘지 않았다.

문법 표지 이해 과제를 위해 먼저 아동이 무언가를 응시하고 있 는 직접경험, 누군가로부터 귀로 내용을 전해 듣고 있는 간접경험, 골똘히 무언가를 생각하는 간접경험을 나타내는 세 가지 그림을 제시한 후 다음과 같은 지시문을 들려주었다. “OO아, 그림 속 첫 번째 친구가 무엇을 하고 있는 것 같아? 맞아, 무엇인가를 보고 있 어. 그럼 두 번째 친구는 어떤 것 같아? 그렇지, 다른 친구의 말을 듣 고 있어. 그렇다면 마지막 친구는? 맞아, 무엇인가를 생각하고 있는 모습이야. 이 친구처럼 내가 직접 본 것, 전해들은 것, 내가 추측하 거나 생각한 것을 다른 사람에게 말할 때, 어떻게 말하면 좋을까? 내가 전해들은 것을 마치 내가 직접 본 것처럼, 혹은 내가 추측한 것 을 전해들은 것처럼 친구에게 말하면 될까? 자, 그럼 친구에게 어떻 게 말하는 것이 좋을지 문제를 풀어 보자.” 검사 과제 18 문항에 대 한 각 보기는 '-네(어)', '-대(래)', '-것 같다'의 문법 표지를 사용한 문 장과 모르겠다가 포함된 사지선다형이었으며, 아동이 조용히 검사 지를 읽고 해결하게 하였다.

마음이론 과제는 먼저 아동에게 그림을 보여주고, 해당하는 이 야기를 육성으로 들려준 다음, 다음과 같은 지시문을 들려주고 질 문에 답하게 하였으며 정답이 존재하지 않는 질문이므로 아동 자 신의 생각을 편하게 대답해 달라고 요청하였다. "OO아, 지금부터 선생님이 그림과 함께 들려주는 이야기를 잘 듣고, 대답하면 돼. 선 생님이 들려주는 질문은 정답이 없어. $\mathrm{OO}$ 이의 생각을 편하게 말해 주면 되는 거야. 잘 할 수 있지? 자 그럼 시작할게.” 그런 다음, 각각 의 과제별 에피소드가 주어지고, 에피소드별로 3-5개의 질문에 답 하도록 하였다. 모든 과제는 그림과 함께 텍스트 형식으로 제시하 였고, 아동이 산출한 내용은 모두 녹음 후 전사하여 분석하였다.

\section{분석 기준과 자료 처리}

\section{문법 표지 이해 과제}

질문에 대해 정확하게 이해하여 정반응한 경우 1 점씩, 총 18 점을 받을 수 있도록 하여 결과를 분석하였다.

\section{마음이론 과제}

우선, '2차 순위 틀린 믿음 과제에서는 한 가지 에피소드에 대해 5 가지 질문을 제시하여, 질문을 정확히 이해하고 답을 한 경우 1 점, 이해하지 못한 경우 0 점으로 총 5 점을 받을 수 있도록 하였다. 두 번 
째, '모호한 상황' 과제에서는 제시한 에피소드에 대해 아동이 얼마 나 마음상태에 근거하여 생각과 기분을 이해하였는지에 따라 분석 하고자 하였다. 따라서 에피소드에 대해 제시된 5 가지 질문에 대해, 무언의 의사전달을 이해한 대답은 2점, 단순 상태를 설명하거나, 상 호작용이 없는 단순 행동 목적의 대답일 경우 1 점, 모르거나 의미 전달이 되지 않는 경우 0 점으로, 총 10 점을 받을 수 있도록 하였다. 마지막으로, '말의 숨은 의미 파악' 과제에서는 두 가지 에피소드 각각에 대해 제시된 3 가지 질문에 대해, 말을 문자 그대로 해석하지 않고 숨은 의미를 파악하거나 마음을 잘 이해한 경우 1 점, 그렇지 못한 경우 0 점으로 채점하였으며, 전체 두 가지 항목 각 3 개의 문항 에 대해 총 6점을 받을 수 있도록 하였다. 따라서 전체 마음이론 과 제에 대해 아동이 받을 수 있는 정반응 점수는 최대 21점이었다.

\section{전체 자료분석 신뢰도}

분석은 연구자 중 1 명과 언어병리학전공 대학원생 (2급 언어재활 사) 1 명이 실시하였으며, 본 연구 절차와 평가방법에 관한 기준을 충분히 공유하고 숙지한 후 진행하였다. 또한 분석한 전체 자료의 $20 \%$ 를 무선 추출하여 평가자 간 신뢰도를 산출하였다. 문법 표지 이해 과제에 대한 평가자 간 신뢰도는 $100 \%$, 마음읽기 능력 과제에 대한 신뢰도는 $98 \%$ 로 평가자 간 분석의 일치도를 보였다.

\section{통계 처리}

학년(2, 4, 6학년)과 세 가지의 문법 표지 유형에 따라 아동의 이 해 발달에 차이가 있는지 알아보기 위해 반복측정된 이원혼합분 산분석(two-way ANOVA with repeated measure)을 실시하였고, 집단 간 차이가 어느 집단 간의 차이인지 알아보기 위하여 사후분 석(Scheffé)을 실시하였다. 그리고 집단 내 문법 표지 유형에 따른 이해 발달에서 유의미한 차이가 나타나는지 알아보기 위해서는 $t$ 검정을 실시하였다. 또한 마음이론 발달의 집단 간 차이에 대해서 는 일원분산분석(one-way ANOVA)을 실시하였고, 이후 사후분석 (Scheffé)을 실시하였다. 학년에 따른 증거성표지 이해와 마음이론 간의 상관을 알아보기 위해서는 추가로 적률상관분석(Pearson

Table 2. Descriptive statistics of grammatical markers according to grade

\begin{tabular}{lcccc}
\hline Grade & $\begin{array}{c}\text { Direct } \\
\text { experience }\end{array}$ & $\begin{array}{c}\text { Indirect } \\
\text { experience }\end{array}$ & $\begin{array}{c}\text { Indirect } \\
\text { inference }\end{array}$ & Total \\
\hline $2(\mathrm{~N}=25)$ & $5.56(.87)$ & $4.04(1.57)$ & $4.08(2.25)$ & $4.56(1.56)$ \\
$4(\mathrm{~N}=25)$ & $5.80(.65)$ & $5.32(1.28)$ & $5.80(.50)$ & $5.64(.81)$ \\
$6(\mathrm{~N}=22)$ & $6.00(.00)$ & $5.90(.43)$ & $6.00(.00)$ & $5.97(.14)$ \\
Total & $5.78(.65)$ & $5.06(1.43)$ & $5.26(1.60)$ & $5.37(1.23)$ \\
\hline
\end{tabular}

Values are presented as mean (SD). correlation)을 실시하였다.

본 연구에서 수집된 모든 자료들의 통계처리는 SPSS ver. 18.0 프 로그램을 사용하였다.

\section{연구 결과}

\section{학년(2, 4, 6학년)에 따른 문법 표지(직접경험, 간접경험, 간접추론) 이해 발달}

학년에 따른 문법 표지 이해 발달에 대한 기술통계 결과는 Table 2 와 같다. 직접경험과 간접경험, 간접추론 모두 아동의 학년이 높아 짐에 따라 점차 수행 점수가 높아졌음을 확인할 수 있었다. 또한 세 집단 모두에서 직접경험의 문법 표지 '-네(어)' 문항의 이해에 대한 정반응 점수가 가장 높았으며, 뒤이어 간접추론과 간접경험의 순으 로 나타났다. 이와 같은 결과가 통계적으로 유의한지 알아보기 위 해 분산분석을 실시한 결과, 학년에 따른 주효과 $\left(F_{(2,69)}=22.599\right.$, $p<.001)$ 가 유의미하였고, 문법 표지에 따라서도 주효과 $\left(F_{(2,138)}=\right.$ $9.179, p<.001)$ 가 나타났다. 학년과 문법 표지 간의 상호작용 효과 또한 통계적으로 유의미하게 나타났다 $\left(F_{(4,138)}=5.376, p<.001\right)$.

학년에 따른 주효과가 나타남에 따라 이러한 차이가 어떠한 집 단 간의 차이인지 알아보기 위해 사후분석을 실시한 결과, 간접경 험을 나타내는 '-대(래)'의 문법 표지에서 2학년과 4학년, 2 학년과 6 학년 간에 집단 간 차이가 나타났으며 $(p<.05)$, 간접추론을 나타내 는 '것 같다'의 문법 표지에서 2 학년과 4 학년, 2 학년과 6 학년 간에 집단 간 차이를 발견할 수 있었다 $(p<.05)$. 또한 전체 문법 표지 총 점에서도 2 학년과 4 학년, 2 학년과 6 학년에서 유의미한 차이가 있 음을 확인하였다 $(p<.05)$.

문법 표지에 따라서도 주효과가 나타남에 따라 어떠한 문법 표 지 간에 통계적으로 유의미한 차이가 있는지를 알아보기 위해 대 응표본 $t$-검정을 실시한 결과, 2 학년 집단에서 직접경험과 간접경험 $(t=4.442, p<.001)$ 직접경험과 간접추론 $(t=3.517, p<.01)$ 의 수행 에 유의미한 차이를 보였으나, 4 학년과 6 학년에서는 집단 내 문법 표지 이해 간에 유의미한 차이가 나타나지 않았다.

Table 3. Descriptive statistics of development of theory of mind (ToM) according to grade

\begin{tabular}{lc}
\hline Grade & ToM \\
\hline $2(\mathrm{~N}=25)$ & $12.00(2.45)$ \\
$4(\mathrm{~N}=25)$ & $14.44(2.48)$ \\
$6(\mathrm{~N}=22)$ & $16.45(2.22)$ \\
Total & $14.21(2.98)$ \\
\hline
\end{tabular}

Values are presented as mean (SD). 


\section{학년(2, 4, 6학년)에 따른 마음이론 발달}

학년에 따른 마음이론 과제 수행에 따른 기술통계 결과는 Table 3 과 같다. 아동의 학년이 높아짐에 따라 마음이론 과제 수행 점수 역시 높아졌으며, 분산분석을 실시한 결과에서도 학년에 따른 유 의미한 차이가 나타났다 $\left(F_{(2,69)}=20.429, p<.001\right)$. 집단 간 차이를 확인하기 위해 사후분석을 실시한 결과에서는, 2 학년과 4 학년, 2 학 년과 6학년, 4 학년과 6 학년 모두에서 유의미한 차이가 나타났다 $(p<.05)$.

\section{학년(2, 4, 6학년)에 따른 문법 표지(직접경험, 간접경험, 간접추론) 이해와 마음이론의 상관관계}

전체 학년의 문법 표지 이해와마음이론 과제 간의 상관분석 결과, 직접경험의 문법 표지와 간접추론의 문법 표지 $(r=.433, p<.001)$, 문법 표지 총점 $(r=.569, p<.001)$ 간에 유의한 상관이 나타났으며, 간접경험의 문법 표지와 간접추론의 문법 표지 $(r=442, p<.001)$, 문법 표지 총점 $(r=.787, p<.001)$, 마음이론 총점 $(r=.346, p<.01)$ 간에도 유의미한 상관이 있음을 확인할 수 있었다. 또한 간접추론 의 문법 표지와 문법 표지 총점 $(r=.870, p<.001)$, 마음이론 총점 $(r=.278, p<.05)$ 간에도 유의한 상관을 확인할 수 있었다. 문법 표 지 총점과 마음이론 총점 $(r=.344, p<.01)$ 간에도 유의한 상관이 있었지만, 직접경험의 문법 표지는 간접경험의 문법 표지, 마음이 론 총점과 유의한 상관이 나타나지 않았다.

\section{논의 및 결론}

본 연구는 초등학교 $2,4,6$ 학년 학생들이 우리말에서 문법 표지 를 이해하는 데 어려움이 있는지, 특히 직접경험, 간접경험 그리고 간접추론을 나타내는 문법 표지의 이해가 다른 사람의 마음 상태 를 추론해내는 마음이론 능력과 관련이 있는지를 알아보고자 하 였다. 이를 위해 직접경험을 나타내는 '-네(어)', 간접경험을 나타내 는 '-대(래)', 그리고 간접추론을 나타내는 '-것 같다'에 대한 이해를 문장이해 과제로 살펴보았다. 또한 마음이론 이해과제를 위해, 총 4 가지 과제를 통해, 특정 사실을 접하지 못해 틀린 믿음을 가진 사람 의 마음과 그 사실을 알고 있는 주인공의 마음을 아동이 이해하는 지, 모호한 상황에 처한 주인공들의 마음과 기분에 대해 이해하는 지, 그리고 말 이면의 숨겨진 뜻을 파악하는지를 알아보고자 하였 으며, 이러한 마음이론 이해와 앞서 살펴본 문법 표지(직접경험, 간 접경험, 간접추론) 이해 발달이 서로 관련이 있는지를 분석하였다. 연구 결과, 학년에 따른 문법 표지 이해 과제에서 직접경험의 표지 는 2학년을 포함한 전체 아동 집단 모두에서 이해에 어려움이 없었
다. 하지만, 간접경험과 간접추론의 표지는 2 학년 아동이 특히 어려 움을 보였으며, 학년이 올라갈수록 이해력이 증가하였기에 학년에 따른 발달적 차이를 확인할 수 있었다. 마음이론 과제의 발달에서 도 학년이 올라갈수록 과제 이해력이 높아짐을 통계적으로 확인할 수 있었다. 또한 문법 표지(직접경험, 간접경험, 간접추론) 이해 과제 와 마음이론 과제 수행 사이의 상관을 살펴본 결과, 직접경험을 제 외한 간접경험 표지와 간접추론 표지에서 마음이론 과제 수행과 상관이 있음을 확인할 수 있었다.

이러한 결과를 통해 생각해 볼 때, 정보의 출처를 밝히고 습득 방 법을 문법적으로 나타내는 문법 표지 중 선행연구에서 비교적 일 찍 발달하는 것으로 알려진 '네(어)'는 본 연구에서 확인한 결과에 서도 학령 전에 이미 완성되는 것으로 보여진다. 이러한 결과는 저 학년인 2학년에서는 3 가지 문법 표지 이해에 대한 집단 내 차이가 유의미했던 반면, 4 학년과 6 학년에서는 집단 내에 유의미한 차이가 나타나지 않았던 점에서도 확인할 수 있었다. 즉, 서술적 담화의 형 태인 직접경험 관련 표현이 비교적 학령 전에 일찍 습득되는 반면, 간접경험을 나타내는 '-대(래)', 그리고 간접추론을 나타내는 '-것 같다'의 발달은 4 학년에 이르러서야 완전히 습득되는 것으로 확인 되었다. 이는 한국어에서의 ‘대'의 이해 발달은 5-6세에 이르러서 도 성숙하지 않은 것으로 보이며, '-것 같다'의 산출이 5세 이후에야 이해와 더불어 급격히 발달되는 경향을 보인다는 Choi 등(2011)의 연구 결과를 뒷받침한다. 실제 학교 생활에서 고학년은 교사의 탈 맥락적 지시에 따르거나 여러 정보를 수집하여 다른 사람에게 전 달해야 하는 설명하기와 이야기, 대화와 같은 담화기술의 습득이 중요해지는 시기(Paul, 2012; Scott, 1994)이다. 따라서 고학년으로 올라갈수록 설명담화의 비중이 높아지는 교과내용에 비추어볼 때, 간접경험과 간접추론을 나타내는 문법 표지의 이해는 4 학년까 지 꾸준히 발달하다가 이후 시기부터는 안정화 된다고 해석해 볼 수 있다.

본 연구에서는 학년에 따른 마음이론 발달에서의 차이가 모든 집단 간에서 유의미하게 나타났다. 이는 마음이론 능력이 학령기 와 그 이후에도 계속 발달한다는 선행연구와 일치한다 (Ghim et al., 2007). 전체 학년별 대상자를 통해 검토하지는 못했지만, 학령 기 전반에 걸친 마음이론의 발달을 본 연구의 결과에서도 확인할 수 있었으므로, 학령기 아동의 성공적인 의사소통을 위한 교육 및 중재에서도 이러한 마음이론의 기여는 보다 구체적으로 적용될 수 있어야 할 것이다.

본 연구의 결과에서 한 가지 주목할 만할 사실로, 문법 표지 '-대 (래)'와 '-것 같다'에 대한 이해가 높은 학령기 아동들의 경우에는 마음이론 과제에서도 높은 수행력을 보이는 경향이 나타났다. 학 
령전 아동을 대상으로 한 선행연구들 역시 정보의 출처를 나타내 는 표현의 이해와 사용에 마음이론 발달이 관여할 수 있음을 제안 하였으므로(Aksu-Koc \& Alici, 2000; Choi et al., 2011), 이러한 경 향이 학령기 발달에서도 여전히 이어지고 있음을 본 연구 결과가 뒷받침한다고 생각된다. 또한 마음이론의 발달이 문장 형식으로 표현되는 문법 표지 이해에도 중요한 역할을 한다는 점과, 특히 한 국어에서 초기 발달 단계에서부터 이뤄지는 문법 표지 이해의 발달 적 기여도를 학령기에도 확인할 수 있었다. 하지만 본 연구에서 살 펴본 특정 문법 표지들의 이해와 발달이 학령전기에 완성되지 못 함에도 불구하고, 학령기 아동의 발달적 특성에 대한 연구들은 거 의 이뤄지지 못하고 있어, 추후 연구의 방향성으로 제시하고자 한 다. 이와 더불어 학령기에 요구되는 다양한 담화 상황에서 정보의 원천을 확인하고 대화적 상호작용에 어려움이 없도록 학령기에도 다양한 문법 표지에 대한 교육과 중재가 필요함을 확인할 수 있었 다는 데 본 연구의 의의가 있다.

학령기 아동의 마음이론 발달을 살펴보기 위하여 본 연구에서 는 총 4 가지의 다양한 과제를 실시하였지만, 문법이해 점수와의 관 련성을 살펴보는 것이 연구의 주목적이었으므로, 상관 관계 분석 을 위해 전체 4 가지 마음이론 과제의 총점만을 분석 대상으로 하였 다. 따라서 마음이론 능력을 평가하기 위한 다양한 과제들 즉, 틀린 믿음을 가진 사람의 마음과 그 사실을 알고 있는 주인공의 마음을 아동이 이해하는지, 모호한 상황에 처한 주인공들의 마음과 기분 에 대해 이해하는지, 그리고 말 이면의 숨겨진 뜻을 정확하게 파악 하는지에 관련된 각 마음이론 과제들과 문법 표지 간의 독립적인 관련성에 대해서는 분석하지 못하였다는 한계가 있다.

본 연구에서는 선행연구들이 학령전 아동을 대상으로 문법 표 지 이해와 산출을 살펴보는 과정에서 아동이 실험자와 함께 직접 상황 정보를 이해하여 산출에 참여하거나, 동영상을 통해 등장 인 물의 상황을 추론해야 하는 등 높은 과제 난이도로 인해 나타나는 문제점을 해결하기 위하여 읽기과제를 사용하였다. 읽기가 가능한 학령기 아동을 대상으로 '-야, '-대(래)' ' '것 같아'가 포함된 사지선 다형의 문장이해 과제를 사용하였지만, 아동들이 행해야 하는 수 행 목표를 전달하는 과정에서 선행연구들과 마찬가지로 어려움을 겪었다. 이러한 연구 절차에서의 어려움은 추후 연구에서 고려되어 야 할 사항으로 남는다. 또한 한국어에서 간접추론과 간접경험을 나타내는 표지들에 대한 습득 연구가 매우 제한적인 상황에서 문 장과제의 제작에서도 학령기 아동 대상의 적절한 문장을 선정하 는 것이 쉽지 않았으며, 이와 더불어 이해 발달만을 살펴보았다는 제한점이 있다. 따라서 추후 연구에서는 좀 더 다양한 문법 표지들 을 포함한 문장이해 과제를 사용하여 학령기 아동의 경험과 추론
을 나타내는 문법 표지의 산출과 이해를 모두 살펴볼 필요가 있을 것이다.

\section{REFERENCES}

Aikhenvald, A. Y. (2004). Evidentiality. Oxford: Oxford University Press.

Aksu-Koc, A., \& Alici, D. M. (2000). Understanding sources of beliefs and marking of uncertainty: the child's theory of evidentiality. In E. V. Clark (Ed.), The proceedings of the thirtieth child language research forum (pp. 123-130). Stanford, CA: Center for the Study of Language and Information.

Astington, J. W., \& Baird, J. A. (2005). Representational development and false-belief understanding. In Why language matters for theory of mind (pp. 163-185). New York: Oxford University Press.

Astington, J. W., \& Jenkins, J. M. (1999). A longitudinal study of the relation between language and theory-of-mind development. Developmental Psychology, 35, 1311-1320.

Baron-Cohen, S., O’Riordan, M., Stone, V., Jones, R., \& Plaisted, K. (1999). Recognition of faux pas by normally developing children and children with Asperger syndrome or high-functioning autism. Journal of Autism and Developmental Disorders, 29, 407-418.

Bartsch, K., \& Wellman, H. M. (1995). Children talk about the mind. New York: Oxford University Press.

Bosacki, S., \& Astington, J. W. (1999). Theory of mind in preadolescence: relations between social understanding and social competence. Social Development, 8, 237-255.

Choi, H. (2007). Mind reading and social skills of adolescence (Master's thesis). Chungbuk National University, Cheongju, Korea.

Choi, Y., Jang, N., \& Lee, H. (2011). Development of evidentiality: production, comprehension and it's relation to theory of mind. Korean Journal of Developmental Psychology, 24, 93-108.

Choi, Y., \& Kaufman, A. (2009). Development of understanding of the information source expression. Proceedings of the Korean Society for Developmental Psychology Autumn Symposium, Seoul, Korea,

Choi, Y., Lee, H., \& Jang, N. (2010). Development of understanding the relationship between information source and certainty. Korean Journal of Developmental Psychology, 23, 109-124.

De Villiers, J. (2000). Language and theory of mind: what are the developmental relationships? In S. Baron-Cohen, H. Tager-Flusberg, \& D. J. Cohen (Eds.), Understanding other minds: perspectives from developmental 
cognitive neuroscience (pp. 83-123). Oxford: Oxford University Press.

Ghim, H. R., \& Kim, S. (2002). Developmental changes in understanding the false belief: teaching effects on the 3- to 5-year-olds' performances. Korean Journal of Developmental Psychology, 15, 33-54.

Ghim, H., Koo, J., Kim, K., Yang, H., Chung, M., Choi, H., ..., \& Yi, S. (2007). Understanding of mind after 7 years of age: mindreading in ambiguous situations. Korean Journal of Developmental Psychology, 20, 21-49.

Gleason, J. B. (2005). The development of language (6th ed.). Boston, MA: Allyn \& Bacon.

Grice, H. P. (1975). Logic and conversation. In P. Cole \& J. L. Morgan (Eds.), Speech arts (pp. 41-58). New York: Academic Press.

Grice, H. P. (1978). Further notes on logic and conversation. In P. Cole \& J. L. Morgan (Eds.), Pragmatics (pp. 113-127). New York: Academic Press.

Happé, F. G. (1994). An advanced test of theory of mind: understanding of characters' thoughts and feelings by able autistic, mentally handicapped, and normal children and adults. Journal of Autism and Developmental Disorders, 24, 129-154.

Jeong, M., \& Hwang, M. (2007). Grammaticality judgments in children with specific language impairment: detection of erroneous case-markers. Korean Journal of Communication Disorders, 12, 587-606.

Jung, K., \& Pae, S. (2010). The grammatical judgement in school-aged children with specific language impairment. Korean Journal of Communication Disorders, 15, 619-631.

Kim, H. (2001). Development of understanding of mind. In H. Sung et al. (Eds.), Cognitive development. Seoul: Hakjisa.

Kim, J. (2012). A study on the terminologies of Korean semantics. Korean Semantics, 39, 101-124.

Kim, M. (2003). The judgemetal abilities of grammaticality in 5 to 7 year-old children (Master's thesis). Dankook University, Yongin, Korea.

Kim, Y. T., Hong, G. H., Kim, K. H., Jang, H. S., \& Lee, J. Y. (2009). Receptive \& expressive vocabulary test (REVT). Seoul: Seoul Community Rehabilitation Center.

Lee, C. (2009). Acquisition of modality. In C. Lee, G. B. Simpson, Y. Kim, \& P. Li (Eds.), Handbook of east Asian psycholinguistics Vol. 3: Korean (pp. 187220). Cambridge: Cambridge University Press.

Lee, H. (2012). Development of evidentiality in Korean (Master's thesis). ChungAng University, Seoul, Korea.

Lee, S. (2000). The acquisition of Korean grammatical morphemes in early childhood. Korean Journal of Child Studies, 24, 51-68.

Lee, S. H., \& Hwang, M. (2002). The development of three Korean semantic particles (nun, man, do) in 3 to 6 year-old children. Korean Journal of Communication Disorders, 7, 24-45.

Lee, Y. (2007). Validity and reliability analyses of the language test of schoolaged children. Korean Journal of Communication Disorders, 12, 569-586.

Lee, Y. J., Lee, J. S., \& Shin, E. S. (2004). Differences in young children's levels of language functions of pretend play, vocabulary, and mental state term expressions for young children according to the theory of mind. Korean Journal of Early Childhood Education, 24, 141-161.

O’Connor, T. G., \& Hirsch, N. (1999). Intra-Individual differences and relationship-specificity of mentalising in early adolescence. Social Development, 8, 256-274.

Pae, S. (2006). Grammatical development of Korea young children. Korean Linguistics, 31, 31-45.

Papafragou, A., Li, P., Choi, Y., \& Han, C. H. (2007). Evidentiality in language and cognition. Cognition, 103, 253-299.

Paul, R. (2012). Language disorders from infancy through adolescence: assessment \& intervention (4th ed.). St. Louis, MO: Elsevier.

Perner, J., Leekam, S. R., \& Wimmer, H. (1987). Three-year-olds' difficulty with false belief: the case for a conceptual deficit. British Journal of Developmental Psychology, 5, 125-137.

Ruffman, T., Slade, L., Rowlandson, K., Rumesy, C., \& Garnham, A. (2003). How language relates to belief, desire, and emotion understanding. Cognitive Development, 18, 139-158.

Scott, C. M. (1994). A discourse continuum for school-age students: impact of modality and genre. In G. P. Wallach \& K. G. Butler (Eds.), Language learning disabilities in school-age children and adolescents (pp. 219-252). New York: Merrill.

Seo, H. S., \& Lee, S. H. (1999). The development of connective ending of 2-5 year old normal children. Korean Journal of Communication Disorders, 4, 167-185.

Song, J. M. (2009). Epistemic modality and evidentiality. Korean Linguistics, 44, 27-53.

Song, Y. J. (2006). Children's inferring word meaning from understanding of the speaker's mind. Korean Journal of Child Studies, 27, 167-180.

Wellman, H. M. (1990). The child's theory of mind. Cambridge, MA: MIT Press.

Westby, C. (2006). There's more to passing than knowing the answers. In T. A. Ukrainetz (Ed.), Contextualized language intervention: scaffolding Prek-12 literacy achievement (pp. 319-388). Austin, TX: Pro-Ed. 
Appendix 1. 문법 표지 문장이해과제의 예

1. 민수는 교실 창문이 깨진 것을 보았다.

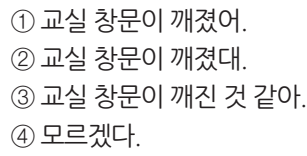

2. 은희는 선물상자에서 달콤한 냄새가 나는 것으로 보아 선물이 초콜릿이라고 추측하였다.

(1) 선물이 초콜릿이네.

(2) 선물이 초콜릿이래.

(3) 선물이 초콜릿인 것 같아.

(4) 모르겠다.

3. 영호는 밖에 비가 온다는 것을 지혜에게 전해 들었다.

(1) 밖에 비가 오네.

(2) 밖에 비가 온대.

(3) 밖에 비가 오는 것 같아.

(4) 모르겠다.

4. 민준이는 환희의 얼굴에 묻은 과자가루를 보고 환희가 과자를 먹었다고 추측하였다.

(1) 환희가 과자를 먹었어

(2) 환희가 과자를 먹은 것 같아.

(3) 환희가 과자를 먹었대.

(4) 모르겠다.

5. 준수는 혜민이가 영화관에 갔다는 것을 민지에게 전해 들었다

(1) 혜민이가 영화관에 갔대.

(2) 혜민이가 영화관에 간 것 같아.

(3) 혜민이가 영화관에 갔어.

(4) 모르겠다. 
Appendix 2. Theory of mind task (마음이론 과제)

\begin{tabular}{llcc}
\hline 과제의 유형 & \multicolumn{1}{c}{ 과제의 목적 } & 에피소드 & 질문 문항수 \\
\hline 2차 순위 틀린 믿음 & 다른 사람의 생각에 대해 잘못 알고 있는 사람의 틀린 믿음을 이해할 수 있는지 파악 & '생일선물' \\
모호한 상황 & 여러 가지 의미로 해석될 수 있는 애매한 행동의 다양한 의미를 파악 & '그네 타는 소녀' \\
말의 숨은 의미 파악 & 마음상태를 알려주는 분명한 단서가 없는 상황에서 마음상태를 파악하거나 말을 문자 & '선의의 거짓말'(목도리) & 5 \\
& 그대로 이해하지 않고 숨은 뜻을 파악 & '풍자'(예의 바른 아이) & 3 \\
& & 3 & 3 \\
\hline
\end{tabular}

예시 - 말의 숨은 의미 파악과제의 '풍자'(예의 바른 아이)

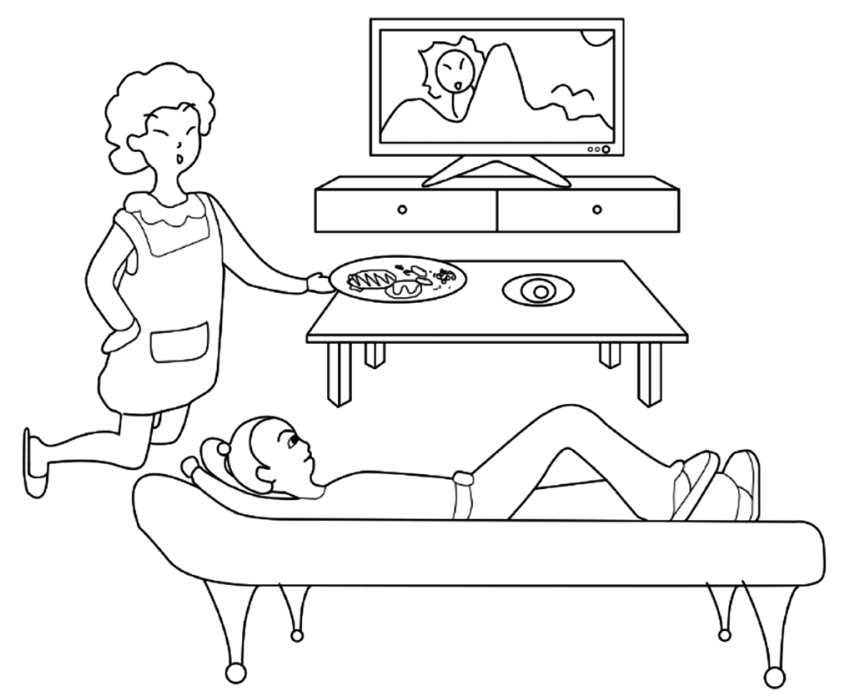

에피소드: 엄마가 초등학교 5학년 된 딸 영희를 위해 열심히 음식을 만들어 테이블로 가져왔어. 그 때 영희는 테이블 옆 소파에 누워 TV만 열심히 보면서 엄마는 쳐다보 지도 않았어. 엄마는 "영희는 정말 예의가 바른 아이야."라고 말했어.

확인질문: "영희는 정말 예의 바른 아이니?"

Q -1. 엄마는 왜 영희는 정말 예의 바른 아이라고 말했을까?

$\mathrm{Q}$-2. 영희는 엄마 말을 듣고 어떤 생각을 할까?

$\mathrm{Q}$-3. 영희의 생각은 맞는 거니? 


\title{
국문초록
}

\author{
학령기 아동의 문법 표지 발달과 마음이론 간의 관계: 경험과 추론을 중심으로 \\ 이지현 · 이희란 \\ 부산가톨릭대학교 언어청각치료학과
}

배경 및 목적: 본 연구에서는 학령기 아동에게서 경험과 추론을 나타내는 문법 표지를 이해하는 능력이 마음이론의 발달과 어떠한 관 련성이 있는지를 살펴보고자 하였다. 방법: 초등학교 $2,4,6$ 학년에 재학 중인 일반아동 72 명을 대상으로 경험과 추론의 문법 표지인 '-네(어), -대(래), -것 같다'에 대한 이해과제와 마음이론과제를 실시하였다. 결과: 간접경험의 '-대(래)'와 간접추론의 '-것 같다'는 4학년 과 6학년에서 이해력이 높아져 고학년에 안정적이 되는 발달적 특징을 확인하였으나, 직접경험의 ‘-네(어)’ 이해는 학년에 따른 차이가 유의미하지 않았다. 마음이론과제 수행은 학년에 따른 유의미한 차이가 있었으며, 상관분석에서도 간접경험과 간접추론 표지, 문법 표 지 총점과 유의한 상관이 있었다. 논의 및 결론: 경험과 추론의 문법 표지 발달은 초등 고학년에서도 마음이론 발달과 상호 관련성이 있으며, 이러한 마음이론과 문법 표지의 발달은 학령기 언어진단과 중재에서 주요 영향요인임을 논의하였다.

핵심어: 학령기 아동, 문법 표지 발달, 마음이론, 화용 발달

본 연구는 제1저자의 석사학위 논문을수정·보완하였음.

\section{참고문헌}

김명희(2003). 5-7세아동의 문법성 판단능력: 조사를 중심으로. 단국대학교대학원 석사학위논문.

김영태, 홍경훈, 김경희, 장혜성, 이주연(2009). 수용·표현어휘력검사(REVT). 서울: 서울장애인복지관.

김진웅(2012). 한국어 증거성의 체계: 유형론을 중심으로. 한국어의미학, 39, 101-124.

김혜리(2001). 마음에 대한 이해 발달. 성현란 외(편). 인지발달. 서울: 학지사.

김혜리, 구재선, 김경미, 양혜영, 정명숙, 최연옥, 이수미(2007). 학령기와 그 이후의 마음이해 발달: 애매한 상황에서의 마음읽기 능력. 한국심리학회

지: 발달, 20, 21-49.

김혜리, 김수진(2002). 학습효과로 살펴본 틀린 믿음 이해능력의 발달적 변화. 한국심리학회지: 발달, 15, 33-54.

배소영(2006). 한국어 발달특성과 학령전기 문법형태소. 한국어학, 31,31-45.

서희선, 이승환(1999). 2-5세 정상아동의 연결어미 발달. 언어청각장애연구, 4, 167-185.

송영주(2006). 단어의미 추론에서 나타나는 아동의 마음이론. 아동학회지, 27, 167-180.

송재목(2009). 인식양태와 증거성. 한국어학, 44, 27-53.

이순형(2000). 한국아동이 초기에 획득한 문법적 형태소의 종류 및 획득 시기. 아동학회지, 24, 51-68.

이승희, 황민아(2002). 3-6세 한국아동의 보조사 발달에 관한 연구: 은/는, 만, 도. 언어청각장애연구, 7, 24-45.

이영자, 이종숙, 신은수(2004). 유아의 마음이론 수준에 따른 가장놀이의 언어기능 수준, 어휘력, 정신상태용어 사용능력 발달. 유아교육연구, 24, 141-161.

이윤경(2007). 학령기 언어검사 도구 개발: 타당도와 신뢰도 분석을 중심으로. 언어청각장애연구, 12, 569-586.

이화인(2012). 한국아동의 증거성표지 발달 과정: 산출, 이해, 확실성 차이에 대한 이해를 중심으로. 중앙대학교대학원 석사학위논문.

정경희, 배소영(2010). 초등 저학년 단순언어장애 아동의 문법형태소 판단 능력. 언어청각장애연구, 15, 619-631.

정미란, 황민아(2007). 단순언어장애 아동의 문법성 판단: 조사 오류를 중심으로. 언어청각장애연구, 12, 587-606.

최영은, A. Kaufman, (2009). 정보 원천 표현에 대한 암묵적 이해의 발달. 한국발달심리학회 추계학술심포지엄 발표논문.

최영은, 이화인, 장나영 (2010). 정보 원천 표현에 따른 정보 확실성 이해의 발달. 한국심리학회지: 발달, 23, 109-124.

최영은, 장나영, 이화인(2011). 증거성표지의 이해, 산출과 마음이론발달의 관련성 연구. 한국심리학회지: 발달, 24, 93-108.

최현옥(2007). 청소년의 마음읽기와사회적 능력. 충북대학교대학원 석사학위논문. 